\title{
Methods of Safety Estimation in Road Traffic with Taking Pedestrian Traffic Problems into Consideration
}

\author{
Marzenna Dębowska-Mróz * \& Elżbieta Szychta * \\ Technical University of Radom, Faculty of Transport and Electrical Engineering, Radom, POLAND \\ *Corresponding author:m.mroz@pr.radom.pl,e.szychta@pr.radom.pl
}

DOI: $10.2478 / \mathrm{v} 10158-010-0010-4$

\begin{abstract}
In this paper basic data are presented which characterise the state of road traffic safety in Poland, and methods of road traffic safety danger estimation are characterised.
\end{abstract}

KEY WORDS: transport, pedestrian, safety, methods of estimation safety danger.

\section{INTRODUCTION}

From earliest times, factors determining the spatial form and transportation system of the first clusters of human, then cities, were human physical abilities (pedestrian), enabling it to change the place of residence and to travel distances. Designing city buildings and road networks was guided by the pedestrians' safety and convenience. For example, Leonardo da Vinci created a project of a city where pedestrian and vehicular traffic were separated, which, according to him, would insure optimal conditions for both ways of traffic. With the design of the first vehicle and the development of motorisation the situation began to change. Cities formed for the safety and convenience of pedestrians didn't match the needs of the increasing number of cars which required more space. Although the development of motorisation undoubtedly brought both social and economic advantages, it also caused many negative events, among others adding to environmental pollution, noise, direct human health risks and life hazards. Cars "forced" pedestrians to be on pavements and brought about the necessity of using the many road signs and light signals which determine the method of road traffic.

\section{THE NATIONAL PROGRAM OF ROAD TRAFFIC SAFETY - „GAMBIT 2005”}

The increasing number of vehicles which are travelling on roads has caused the worsening condition of road traffic safety. About half million people die every year in the world. In Poland in 200749536 [1] road accidents occurred, in which 5583 people died and 63224 were injured.

Taking road traffic safety into consideration ministries accepted and started to realise the National Traffic Road Safety Program - "Gambit 2005" at a cabinet meeting on $19^{\text {th }}$ April 2005. In this program has aims for the next few years. The main purpose of the program is in decreasing the number of victims by over $50 \%$ for 2013 in relation to 2003. 
The main purpose of the National Traffic Road Safety Program "Gambit 2005" would be able to be realised possibly due to the realisation of the following partial aims $[4,5,8]$ :

- Purpose 1: $\quad$ Creating a basis to conduct efficient and long-term activities for road traffic safety.

- Purpose 2: $\quad$ Forming a safe attitude of road traffic participants.

- Purpose 3: Pedestrians, children and cyclists protection.

- Purpose 4: $\quad$ Creating and keeping a safe road infrastructure.

- Purpose 5: Decreasing the seriousness and consequences of road accidents.

To realise the purposes of the "Gambit 2005" program it is necessary to take into account designing proper programs and set of guidelines which determine the rules of all functioning subjects in road traffic. These programs should allow for all essential parameters which decide about transport process realization. For this reason it is necessary to recognize the reasons, circumstances and accidents effects to efficiently prevent or ease their consequences. The essential task helpful in the proposed realization of “Gambit 2005" is estimating road traffic safety.

\section{SAFETY ESTIMATION IN ROAD TRAFFIC}

The essence of road traffic safety is the un-conflicted participation in road traffic of all its participants [1,2]. The aim of research into road traffic safety is the analysis of the HUMAN-VEHICLE-ROAD system (and its environment), specifying the possible use of its improvement and effects estimation which result from its research.

In research of road traffic safety most attention is often paid to the systematic and quantitative description of the road traffic safety state.

This can be achieved by:

- statistical specifications;

- statistical indicators;

- regressive dependences;

- operative safe indicators.

The effects of this kind of research are statistical specifications, which present number dependences of road accidents from such features as: accident victim (female/male sex, age group, type of accident result), accident place (in the sense of the kind of road net segment, e.g., junction, straight road section, pedestrian crossing, etc.), kind of vehicle accident participant, kind of accident (head-on collision, running into, vehicle overturning, etc.), manoeuvre during which accident happened, accident causes, and other accident circumstances [1,2]. On the basis of the achieved results it is difficult to determine the real reason for the road accident.

In connection with this it is essential to work out during the analysis of danger in road traffic the answers to the question: who or what is the reason for the danger in road traffic. 
All research agree in admitting that the main role is the "human factor" (driver or pedestrian) in generating accidents dangers [2,7]. Those works come down to first of all determining the connection of the increasing situation of danger in traffic with human physiological parameters.

Another branch of research contains works whose aim is in determining the connection of the roads with road accidents. Those works are conducted in two ways which are possible to separate:

- analysis of dangerous places on roads (the so called problem of "black spots"),

- analysis of the influence of road elements on the level of road accidents.

Research of road influence and traffic conditions on creating a danger to safety in road traffic is most often expressed in the analysis of the influence of road geometric elements on accident levels and in the analysis of dangerous places on roads or its segments.

When discussing the range of road traffic research from a quantitative assessment (which characterizes traffic safety) point of view it is necessary to mention road traffic modelling.

It is interesting to first of all identify motion model parameters which can be helpful in the estimation of its safety. From existing foreign and national literature traffic models there are not many which consider the aspect of traffic safety with pedestrian traffic specifically or in which the verification criteria is traffic safety [2].

Estimation of an accident's danger state is made on the basis of proper indices. For it to be measurable an estimation is considered, e.g., accidents number index (possibly fatalities and injured) per 10 thousand people, 10 thousand cars, or 1 million kilometre-vehicles, danger index, and accident seriousness. The danger index is a synthetic index which considers the intensity of road traffic and the linear density of accidents on road sections. An accident seriousness index estimates the connection of mortalities per 100 accidents occurring.

On the basis of the presented material it can be seen that the measures are not useful for the estimation of pedestrian traffic quality on the area, due to the big variability of parameters, even for the traffic participant.

It can be observed that on the basis of the above mentioned indicators it is difficult to estimate pedestrians' safety in road traffic, because the existing indices relate to the general number of road accidents, vehicles or transport work. Besides, the absolute numbers of dead and injured do not give sufficient information about the danger levels at particular points, possibly on the whole transport network of the city. Such an attitude to danger level estimation testifies that the estimation of road traffic safety level is effectively done due to vehicle traffic and avoiding pedestrian traffic, which is an inseparable part of road traffic.

Another essential problem in road traffic safety analyses (including pedestrians) is a source of information about events in road traffic. From the available literature information on events in road traffic can be received from:

analysis of road accident statistics, analysis of conflict situations, analysis of before conflict situations (states), analysis of simulation methods effects. 
One of the basic problems in road traffic safety research is a deficit of information which allows for a safety analysis by ex ante methods. The basic source of information about events in road traffic is the statistics of road accidents. The main disadvantages of such a kind of information source are the following:

- road accidents are relatively seldom events,

- road accidents give ex post information, what is equal to road traffic victims,

- number of accidents in a specified place is usually small,

- accidents occur in some time interval (sometimes large) and are not comparable because of change in traffic conditions,

- those data are not sufficiently exact (not precisely filled in "cards of road accident"),

- information attained this way allows an event to be placed in a fault category, not the reasons for the accident. The most important advantage of that information source is that thanks to the attained statistics it is possible to observe a general tendency and methods of accident situation development.

The first step on the way to before-accidents analysis is a method of conflict situation in road traffic analysis (Traffic Conflicts Techniques TCT) [1,2,7]. Conflicts technique is used in the estimation of road traffic safety in many countries. The main advantage of this method is a bigger frequency of the conflict situation occurring in road traffic (can be up to 10 times the frequency of road accidents). By using techniques of traffic conflicts can be said about security risks in the stages immediately preceding traffic accident, which often occurs as a not result to take, by the road users, various types of emergency actions (turn, brake, change the speed of traffic).

Necessary information about danger state and its level lend themselves to methods which use before-conflicts state analysis (without the necessity of waiting for road accident or conflict situations). Quantitative analysis of the danger in before-conflict states is possible thanks to using so-called behavioural danger indicators (BIZ). BIZ are potentially dangerous faults of traffic participants or time and space dimensions which indicate the danger state of road traffic safety.

Those values are an effect of the behavior of the traffic system C-P-D in determined traffic - road conditions. By using BIZ the safety danger can be studied in normal traffic - road situations where objective traffic safety danger occurs, but it is accepted or invisible to the traffic participants. The frequency of these occurring before conflict situations is larger than just conflict situations because of the permanent presence of safety danger in road traffic.

Analysis of danger in road traffic using the traffic conflicts techniques method and by using behavioural indicators of danger allow a danger situation estimation in ex ante type road traffic.

Another essential problem in traffic safety research is pointing dangerous places. Pointing dangerous places is made on the basis of generally available information about road events, road, traffic parameters, and thanks to using proper indices. Information about each road event, apart from for registry purposes, can be divided into the following groups:

a. general data about the road event - date and place of event, kind of event and its effects (e.g., human victims); 
b. circumstances and causes of the event - behaviour of traffic participants (driver, edestrian), road information, lighting and weather conditions;

c. detailed information about the place of the event - functional identification, technique parameters, organisation and traffic steering and other features of the event location connected with it;

d. information about traffic at the event location - traffic intensity, quality and direction structure, speed of vehicles stream and intensity of pedestrian traffic;

e. detailed information about traffic participants and vehicle - age, sex, driving licence category, type and make of a car, etc.

Locating dangerous places is also a component element of the general analysis traffic safety state. The purpose of locating dangerous places and also their analysis is recognising reasons for the events occurring in the place. Determining the reasons allow a project to e arried out and improvements to traffic safety (traffic quality) to be made.

Safety estimations (dangers) in road traffic (and also pedestrian traffic) are made most often on the basis of road accidents statistics. Data from road accident cards do not give answers for many of the questions of the accident's circumstances. Detailed and reliable information can be provided only through scrupulous research, thanks to which it would be possible to determine the complicated and various reasons for the accidents. As each road accident has its typical, often repeatable circumstances, successful analysis of road traffic safety danger (and also pedestrian traffic) requires information about the event condition: place, time, traffic conditions (intensity of pedestrian and vehicular traffic, size of kinetic vehicles stream) and reason for the accident. Road accidents can be treated as disturbances in functioning of the system: HUMAN VEHICLE - ROAD.

An estimation of road traffic safety (also from pedestrian point of view) shouldn't only be boiled down to an analysis of the statistics of road accidents, because on that basis it is difficult to define and estimate the factors which influence rising road accidents and their effects. It is therefore necessary to have different types of undertakings which help with determining the proper methods for estimating the level of road traffic safety. This especially concerns standardizing the range of means and research methods.

Proper realization of the activities which follow road traffic safety improvement (and also pedestrians' safety) and achieving the essential economic effects requires the use of proper diagnostic methods. Those methods should allow danger estimation of different accident types (e.g., vehicle-pedestrian type) and simultaneously give indispensable information about dangerous places and the reasons for the accidents rising in those places.

\section{CONCLUSIONS}

From the presented analysis of road traffic safety it follows definitively that the pedestrian traffic problem does not have the correct place in those considerations. In principle separate analysis and danger estimation from a pedestrian point of view are not made. The importance of these matters is only signalled on the occasion of a general analysis of road traffic safety. This is unfortunately the wrong method as accidents with pedestrians involve too many victims (dead and injured). 


\section{REFERENCES}

Dębowska-Mróz, M.: Program likwidacji miejsc niebezpiecznych na drogach na przykładzie regionu radomskiego. Praca niepublikowana. Politechnika Radomska. Radom $2006 \div 2008$.

Dębowska-Mróz M.: Zarządzanie bezpieczeństwem ruchu drogowego. Praca niepublikowana. Politechnika Radomska. Radom $2001 \div 2005$.

Globalne spojrzenie na ofiary wypadków drogowych, Globalne Partnerstwo dla Bezpieczeństwa Ruchu Drogowego, nr 2, 2002 r.

Krajowy Program Bezpieczeństwa Ruchu Drogowego 2005-2007-2013 GAMBIT 2005 (www.krbezpieczensto ruchu drogowego.gov.pl).

Krystek R., 2004: Polityka Transportowa Państwa wywiad z podsekretarzem stanu w Ministerstwie Infrastruktury prof. dr hab. Ryszardem Krystkiem, Bezpieczeństwo Ruchu Drogowego, nr 3.

Krystek R.: Koncepcja programu poprawy bezpieczeństwa ruchu drogowego w Polsce do roku 2000.

Walawski J., 1980: Droga - bezpieczeństwo ruchu. Wydawnictwa Komunikacji i Łączności. Warszawa. 